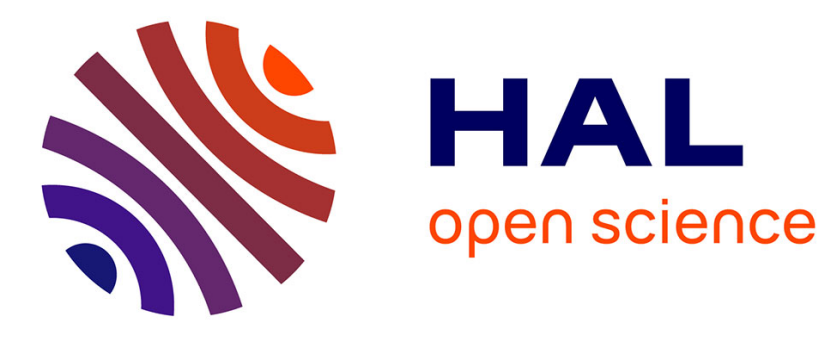

\title{
Groundwater Management Lessons from Chile
}

\author{
Guillermo Donoso, Elisabeth Lictevout, Jean-Daniel Rinaudo
}

\section{To cite this version:}

Guillermo Donoso, Elisabeth Lictevout, Jean-Daniel Rinaudo. Groundwater Management Lessons from Chile. Sustainable groundwater management: a comparative analysis of French and Australian policies and implications to other countries, pp.481-509, 2020, 10.1007/978-3-030-32766-8_25 . hal02532177

\section{HAL Id: hal-02532177 \\ https://hal.science/hal-02532177}

Submitted on 15 Apr 2020

HAL is a multi-disciplinary open access archive for the deposit and dissemination of scientific research documents, whether they are published or not. The documents may come from teaching and research institutions in France or abroad, or from public or private research centers.
L'archive ouverte pluridisciplinaire HAL, est destinée au dépôt et à la diffusion de documents scientifiques de niveau recherche, publiés ou non, émanant des établissements d'enseignement et de recherche français ou étrangers, des laboratoires publics ou privés. 


\title{
Chapter 25. Groundwater Management Lessons from Chile
}

\author{
Donoso, $\mathrm{G}^{1,2}$., Lictevout, $\mathrm{E}^{3,4}$., and Rinaudo J.D. ${ }^{5}$
}

1. Deparment of Agricultural Economics, Pontificia Universidad Catolica de Chile, Santiago, Chile

2. Water Law and Management Center, Pontificia Universidad Catolica de Chile, Santiago, Chile

3. Universidad de Concepcion, Concepción, Chile

4. Carpe Science, San Pedro de la Paz, Chile

5. BRGM (French Geological Survey), Montpellier University, Montpellier, France.

Corresponding author: gdonosoh@uc.cl

\begin{abstract}
Groundwater has increasingly become a water supply source in Chile. In the future this trend is expected to grow as a consequence of the increased water use due to economic growth, together with population growth, urbanization, water contamination and pollution, as well as the projected climate change impacts. The Water Code of 1981, as well as previous water codes, were in essence designed for surface water and, thus, contained only few references to groundwater. This regulatory absence has been covered with groundwater guidelines established through internal administrative acts. As it stands, the legal and institutional context considers the required instruments and mechanisms to balance growing demand and the need to protect and preserve groundwater resources. This chapter investigates whether this framework has been effective to ensure that groundwater is managed sustainably, through the analysis of two cases located in an arid region of northern Chile: the Copiapó Valley and the Pampa del Tamarugal Aquifer.
\end{abstract}

Keywords: Groundwater governance, groundwater management, collective groundwater management, groundwater communities, Chile 


\section{Introduction}

Water has always been a strategic resource for economic development, particularly in the arid and semi-arid regions of the north of Chile. Water supply infrastructures, in particular irrigation systems, were developed by Native Americans even before the Spanish colonial period, allowing for the development of a prosperous agricultural economy in temperate, semi-arid and even arid regions. From the end of the XIX ${ }^{\text {th }}$ century to the 1970 's, the State has heavily invested in the development of large reservoirs which contributed to increase water supply security. As construction costs increased and public funds became relatively scarcer, private sectors increasingly invested in the development of a new series of reservoirs between 19801990. In parallel, many users turned towards groundwater, which was relatively cheap and easy to access both in technical and regulatory terms. As in many other countries, the development of groundwater exploitation has taken place in a relatively weak regulatory framework. And it is only when problems began to appear that the State timidly set up a groundwater management policy.

Thus, over decades, groundwater has gradually become an essential water supply source particularly in northern Chile (Peña et al., 2011). The number of granted groundwater rights increased $4,350 \%$ between 2001 and 2017, while surface water rights grew $207 \%$ during the same period. Today, the importance of groundwater as a water source is particularly evident in the North and Center Macroregions (Table 25. 1). In the future this trend is expected to grow as a consequence of the increased water use due to economic growth, together with population growth, urbanization, water contamination and pollution, as well as the projected climate change impacts on the availability of surface water (Vicuña et al., 2012; Vicuña et al., 2011).

Table 25. 1: Granted Surface and Groundwater Rights (DGA, 2016a)

\begin{tabular}{|c|c|c|c|c|}
\hline \multirow{2}{*}{ Macroregion } & \multicolumn{2}{|c|}{ Surface Water } & \multicolumn{2}{|c|}{ Groundwater } \\
\hline & $\mathrm{N}^{\circ}$ & $1 / \mathrm{s}$ & $\mathrm{N}^{\circ}$ & $1 / \mathrm{s}$ \\
\hline North & 5,826 & 161,145 & 9,097 & 78,536 \\
\hline Center & 8,380 & $1,231,989$ & 24,078 & 290,664 \\
\hline South & 25,381 & $1,209,944$ & 13,136 & 82,517 \\
\hline $\begin{array}{l}\text { Extreme } \\
\text { South }\end{array}$ & 3,359 & 355,848 & 651 & 1,123 \\
\hline
\end{tabular}

The rapid development of groundwater use has generated a number of problems threatening the sustainability of the resources. Groundwater levels have been declining in a number of regions, revealing that aquifers were exploited beyond 
sustainable limits. In many Andean valleys, river base flows significantly decreased, with rivers drying-up in extreme cases, threatening traditional irrigation systems. Dependent ecosystems were also impacted by groundwater depletion. Groundwater over-allocation has increased water conflicts. At first, conflicts concerning groundwater were typically in the North and Center Macroregions of the country. However, the intensification of its use has expanded the territorial extent of such conflicts (Rivera et al., 2016), and everything presumes that their number and complexity will continue to expand.

From the 1990's onwards, there was growing awareness that Chilean water policy and management parctices were inadapted to ensure a sustainable use of groundwater resources. Various problems associated with groundwater management have been identified (Salazar, 2003; World Bank, 2011). A major concern is the general lack of information about groundwater and insufficient knowledge about its dynamics, in particular its interaction with surface waters. There are significant gaps in the registry of wells, extraction and quality measurements, recharge balances, and identification of pollution sources. Furthermore, there is no collective management, due to the lack of effective groundwater user associations. An additional challenge for a sustainable groundwater management is the fact that at present ground and surface waters are managed independently despite their recognized interrelations and even though the 2005 reform of the Water Code of 1981 (WC81) establishes that surface and groundwater must be jointly managed. This implies that conjunctive management of surface and groundwater remains a challenge (Vergara and Rivera, 2018; Briscoe, Anguita, and Peña, 1996). Finally, the effects on the recharge of aquifers of the direct subsidies for the technification of irrigation have not been analyzed.

In spite of several policy responses and changes in the legal framework, evidences of groundwater over-allocation have been growing, increasing concerns over the sustainability of actual groundwater use. The sustainability of northern aquifers is compromised due to the over-allocation of groundwater rights (GWR). For example, McPhee et al. (2012) points out that in the North Macroegion of Chile, where aquifers have a significant role as a source of water resources, mainly for mining and agricultural activities, annual estimated recharge is $10 \mathrm{~m}^{3} / \mathrm{s}$ while average discharge ranges between $10 \mathrm{~m}^{3} / \mathrm{s}$ to $20 \mathrm{~m}^{3} / \mathrm{s}$. A similar situation occurs in the Center Macroregion where annual estimated recharge ranges from $50 \mathrm{~m}^{3} / \mathrm{s}$ to $100 \mathrm{~m}^{3} / \mathrm{s}$, while annual discharge fluctuates between $54 \mathrm{~m}^{3} / \mathrm{s}$ and $120 \mathrm{~m}^{3} / \mathrm{s}$ (DGA, 2016a).

In the following sections, we illustrate the legal and institutional framework for groundwater management in Chile. We then investigate the effectiveness of this framework through the analysis of two case studies. The chapter is organized as follows. It starts with a broad description of the legal and institutional groundwater management scheme in Chile. The chapter then goes on with a presentation of groundwater management in two cases located in an arid region of northern Chile: the Copiapó Valley and the Pampa del Tamarugal Aquifer. The chapter ends with a discussion of the lessons learnt and implications for groundwater management. 


\section{Legal and institutional framework}

The historical evolution of groundwater development and management can be broken down into four major phases. The first phase corresponds to the 1960-1990 period during which groundwater use significantly developed. During those three decades, landowners could freely appropriate the water located beneath their land, obtaining permanent water rights that were granted by the State under different conditions as the law changed in 1951, 1967 and 1981. The end of this phase is marked by the introduction of legal rules allowing to restrict or prohibit new groundwater use in the WC81. The second phase corresponds to the ten years of transition period that followed, during which users resisted the implementation of these procedures, and managed to obtain that new rights be allocated, leading to increased overexploitation and groundwater depletion. Phase 3 covers the period from the mid-2000's to today. It has been marked by the development of an increasingly sophisticated groundwater regulation, and the promotion of a form of co-management implying both the State and groundwater users' associations. The remainder of this sections presents this evolution of the Chilean groundwater policy in more details, looking at five main issues: i) the definition of groundwater property rights; ii) the initial allocation of those rights; iii) procedures implemented to restrict water use when groundwater is overexploited; iv) the establishment of groundwater users' associations; and v) GWR reallocation through markets. Private water use rights: a historical component of water policy in Chile

Water laws and institutions that emerged in Chile during the colonial time, were largely based on those that existed in Spain. Water law in Chile during the precolonial period was strongly influenced by the following two principles of Spanish water law: 1) the principle of Roman law that held that waters were common to all men and therefore could not be part of anyone's private property and, 2) that the use of these same waters could be reclaimed as part of the private property of certain feudal lords (Ugarte Araya, 2003). Thus, under the Laws of the Indies, through an express concession (called Merced), a private person was allowed to acquire property over water rights. Hence, water concessions were expressly granted only for the use of water, and in no way referred to the domain of the water resource (Ugarte Araya, 2003).

Water management in Chile has therefore, been governed throughout its history by water rights (WR) granted by the State. The nature of these rights changed under different legislations. For example, the Supreme Decree of November 18, 1819, the first legal provision with respect to water of the Government of the Republic of Chile, established tradable private water rights. The Water Code of 1951 (Gobierno de Chile, 1951) also granted private tradable water rights. The 1967 code (Gobierno de Chile, 1969), on the other hand, established that water rights were administrative rights that could expire (Hearne and Donoso, 2005). Finally, the Water Code of 1981 (Gobierno de Chile, 1981) maintained water as a national property for public use, granting private tradable water rights and reduced the participation of the State (Montginoul et al., 2016; Vergara and Rivera, 2018); the user is the owner of the 
right in perpetuity, ownership that is protected constitutionally (Vergara and Rivera, 2018; Vergara et al., 2011). Additionally, WR are not sector specific and can be transferred between sectors as well as within economic sectors.

The WC81 specifies that WR can be exercised in a permanent or contingent manner and in a continuous, discontinuous or alternating mode. Permanent WR are rights that authorize the extraction of a specified water flow, unless water supply is insufficient to satisfy all permanent WR and they are recognized as shares of water flows (Vergara and Rivera, 2018; World Bank, 2011). Contingent rights are specified as a volume per unit of time and only authorize the user to extract water once permanent rights have been satisfied. Continuous WR allow users to extract water continually over time, discontinuous rights only permit water extraction at given periods, and, lastly, alternating WR distribute water among two or more persons.

It is important to point out that the WC81, as well as previous water codes, were in essence designed for surface water and, thus, contains only few references to groundwater. Thus, groundwater development has taken place in an institutional setting that put no or few limits on groundwater use (Vergara and Rivera, 2018; Rivera, 2015). This regulatory absence has been covered with groundwater guidelines established by the DGA through internal administrative acts (Rivera, 2015). While this trend has experienced some variations in recent years, the precariousness of the treatment of groundwater remains, in general terms, a characteristic feature of the WC81 which thus, contains insufficient rules to effectively regulate groundwater resources (Vergara and Rivera, 2018; Rivera, 2018).

\subsection{Initial allocation of groundwater use rights}

Historically, the Civil Code and all Water Codes defined groundwater as "water that is hidden within the core of the earth and has not been found". Interested parties must then explore for the existence of groundwater. Any person can explore in order to find groundwater on their own property but requires an authorization by the Directorate General of Water (Dirección General de Aguas - DGA) to do so on public lands (Zañartu Rosselot, 2001). Should two or more petitions for exploration be presented for the same geographic area, the DGA will define who receives the exploration right based on an auction ${ }^{83}$.

Decree No 203 of 2014 (Gobierno de Chile, 2014) sets the legal and technical regulations for groundwater exploitation and exploration. It is only possible to grant groundwater rights (GWR) once it has been verified that groundwater is available (Rivera, 2018; Zañartu Rosselot, 2001), and that its extraction would not affect GWRs of third parties. Therefore, it is not enough to only prove the physical existence of groundwater to obtain a GWR. By strict legal mandate, the DGA must also consider an additional element when studying the availability of groundwater; the exploitation of the aquifer should be appropriate for its conservation and protection

${ }^{83}$ Evidence has shown that auctions have not been frequently used to allocate exploration, as well as GWR requests. 
in the long term, according to the recharge estimates and to existing and foreseeable uses. Thus, the analysis should not only focus on the present situation of the aquifer when assessing the request, but it should consider its projected use, in order to ensure its sustainability.

Thus, in the case that the exploration efforts are successful, and groundwater is found, the user can petition the DGA for a new GWR presenting pumping tests that certify the existence of the requested water flow. This petition must:

(a) Identify the aquifer from which the water is to be extracted;

(b) Define the quantity of water to be extracted, expressed in liters per second;

(c) Specify the yield and depth of the extraction well;

(d) Specify the water extraction points and the method of extraction; and

(e) Define whether the right is permanent or contingent, continuous, discontinuous or alternating.

The GWR petition must be made known to other potential interested parties by being published in the Diario Oficial, in a daily Santiago newspaper, and in a regional newspaper, where applicable. Previous to the WC81 reform of 2005, the DGA could not refuse to grant new GWR without infringing a constitutional guarantee, provided there was technical evidence of the availability of water resources and that the new use would not harm existent rights holders. At present, the DGA can refuse to grant the solicited GWR if the petition is perceived to be for speculative reasons. To assess this, the petitioner must present a brief technical description of the project that requires the GRW. If there is competition for solicited water rights, they are to be allocated through an auction granting the GRW to the highest bidder.

The GWR is specified as a flow rate expressed in liters per second, that is granted in perpetuity and allows its holders total freedom to use the allocated water for the purpose they wish (Lictevout and Faysse, 2018; Vergara and Rivera, 2018; Hearne and Donoso, 2005); thus, GWR are not sector specific (Donoso, 2015). In 2005 the reform of the WC81 changed the required characterization of groundwater rights, specifying both the maximum instantaneous flow and maximum pumped volume per year (Donoso, 2015).

Due to the concern about the lack of effective water use, Law No. 20,017 of 2005, which amended the WC81, introduced a non-use tariff (patente de no-uso). The non-use tariff is applied to all consumptive permanent GWR that do not count with the required pumps and equipment to extract the granted water flow (Gobierno de Chile, 2005). 


\subsection{Procedure to restrict groundwater use to ensure sustainable groundwater exploitation}

Despite the deregulation that prevails in groundwater, the recently approved Law $\mathrm{N}^{\circ} 21,064$ (Gobierno de Chile, 2018) allows for a greater control and administrative intervention of the DGA focused on groundwater availability. Within a framework of sustainability, the Supreme Decree $\mathrm{N}^{\circ} 203$ recognizes the need to regulate groundwater extraction, endowing the DGA with powers to limit the extraction of groundwater when there is evidence that extraction rates have had a direct impact on groundwater levels or existing GWR, declaring a temporary reduction of the exercise of groundwater rights or declaring the aquifer under restriction or under prohibition. GWR remain secure and are not threatened under these limitations (Mechlem, 2016).

In situations where there was proof that extraction rates had a direct impact on groundwater levels or existing GWR, the DGA could limit groundwater use by temporally reducing the allocated groundwater flow, only at the request of an interested party. The possibility of limiting withdrawals has been contemplated since 1983 (Res DGA 207 of 1983). However, this measure has never been implemented in practice; users have never petitioned the DGA to temporarily limit the exercise of their own GWR (Rivera, 2015). Law N ${ }^{\circ} 21,064$ takes this into account and now allows the DGA to take the initiative to temporally reduce the allocated groundwater flow imposing a prorrata ex officio, i.e. in the absence of any request of an interested party.

The declaration of a groundwater resource under restriction is appropriate, as a generic cause, when there is a serious risk of diminishing water levels, with the consequent damage to constituted or recognized GWR. To declare a restriction area, the DGA must present evidence of at least one of the following conditions:

i) there has been a general decline in groundwater levels, affecting groundwater uses;

ii) groundwater extractions exceed the recharge rate, reducing groundwater levels and the volume of water stored in the aquifer by more than $5 \%$ of the total volume over a period of 50 years;

iii) average low flow of springs and surface water have decreased $10 \%$ or more, affecting existing WR;

iv) exploitation generates a risk of groundwater contamination from polluted water or saline intrusion;

v) exploitation induces environmental risks in protected dependent ecosystem due to reduced water flows and groundwater levels.

The declaration of a restricted area can be requested by any water user or the DGA itself as of 2018 (Law N ${ }^{\circ} 21,064$ of 2018). This declaration implies that only provisional GWR can be granted. The allocation of, albeit provisional, rights to an aquifer considered to be in a fragile state may be understood as a way to account for 
uncertainties in hydrogeological studies before a final decision is taken on the appropriate pumping rate (Lictevout and Faysse, 2018). Temporary rights can, in principle, become permanent water rights if they are used continuously for at least five years, on condition that they do not affect other users ${ }^{84}$. Should negative impacts be identified in these areas, these provisional WR can be annulled by the DGA; this was the case in La Ligua-Petorca where the DGA, based on hydrogeological models of the basins, determined that the decreases in the water levels of the aquifers correspond to a permanent deficit and not to a temporary effect. As a result, the totality of the provisional GWRs in these basins were revoked (Res 1703, 2014). The prohibition area arises from the need for greater protection of the aquifer (Rivera, 2018), and, hence, no further rights can be granted.

Approximately $70 \%$ of Chilean territory presents no restrictions for groundwater exploitation. Between 1997 and 2015, 153 restriction areas have been declared in the Central and Northern Macroregions. There are only 5 prohibition areas in the Northern Macroregion and 1 the Central Macroregion (Table 25. 2).

Table 25. 2: Number of aquifers or hydrogeological sectors of common use declared under restriction or prohibition (DGA, 2016a)

\begin{tabular}{|l|c|c|}
\hline Macroregion & $\begin{array}{c}\text { Re- } \\
\text { striction }\end{array}$ & $\begin{array}{c}\text { Prohibi- } \\
\text { tion }\end{array}$ \\
\hline North & 47 & 5 \\
Center & 103 & 1 \\
South & 3 & 0 \\
Extreme & 0 & 0 \\
South & 153 & 6 \\
\hline Total & & \\
\hline
\end{tabular}

Additionally, Law 21064 establishes that whenever a restriction or prohibition area is declared, GWR holders must install and maintain a water flow extraction and volume measurement system and send this information to the DGA. For the fulfillment of this requirement, the DGA may ex officio or based on the complaint of any groundwater user initiate a procedure to sanction non-compliance with this norm. This has not yet been implemented since the DGA has yet to promulgate the required rules of operation .

${ }^{84}$ No provisional GWR have become permanent, even though they have been in use for more than 5 years. 


\subsection{Groundwater user associations or aquifer management organ- izations}

Similar to the legislation of a number of countries, Decree $N^{\circ} 203$ of 2014 provides for the establishment of groundwater user community (comunidad de aguas subterráneas - GUC) or aquifer management organizations. These associations are responsible for the management of the aquifer; more specifically they have the authority to:

i) set limits for each user's pumping rate whenever necessary to avoid a decrease of the water table;

ii) control extractions;

iii) monitor the quality and quantity of groundwater;

iv) report to the DGA extraction levels.

When it comes to decision-making, the number of votes allocated to groundwater users in the GUC is proportional to their groundwater rights (Lictevout and Faysse, 2018).

According to the Water Code and Decree N 203 of 2014, a GUC has to be constituted when an aquifer has been declared a restricted or prohibited area. However, even though we should find at least $159 \mathrm{GUC}^{85}$, only 13 have been in fact established, mostly in the regions of Copiapó and Ligua-Petorca - Valparaíso (DGA, $2016 \mathrm{~b}$ ). The majority of these were created during the last 5 years, and thus are still in an implementation stage.

The fact that users have not yet organized themselves in GUCs to take over the management of groundwater reflects the lack of understanding of a large proportion of users of the long-term effects that uncontrolled exploitation of aquifers may cause. A large part of the users are not aware of the legal possibility of setting up a restriction of use and they have difficulty understanding how this mechanism will be put in place by the GUC.

Additionally, groundwater users are relatively reluctant to create and participate in GUCs, since most of them still consider GUCs as more restrictive in terms of water abstraction than surface associations and they tend to view the process as state controlled (Rinaudo and Donoso, 2018). Moreover, user participation is poor, and this is particularly true of small-scale users since votes are proportional to their allocation of WR. The possibility of exercising the power to resolve conflicts by the administration of a GUC is affected by the low participation and legitimacy of the directory before its users. Thus, in general, the performance of GUCs is poor (Rinaudo and Donoso, 2018; Vergara and Rivera, 2018). This can be explained by the fact that GUCs do not fully satisfy Ostrom's 8 principles for an effective collective groundwater management (Ostrom, 2000). The main difficulties that limit

${ }^{85}$ One for each aquifer or hydrogeological sector of common use declared under restriction or prohibition. 
GUC's effective water management are (Rinaudo and Donoso, 2018; Vergara et al., 2013):

i) Legal and administrative obstacles in the determination of their statutes and rules of operation.

ii) Lack of adequate professional management.

iii) Insufficient budgets for an effective water management.

iv) Administrative presence and intervention in some aquifers.

v) Aquifer sections with autonomous and independent GUC, limiting an integrated water management.

vi) Lack of effective participation of all water users.

vii) Lack of a complete registry of GWR.

Due to these concerns, the DGA, Comisión Nacional de Riego (National Irrigation Committee - CNR), and Dirección de Obras Hidráulicas (Public Works Directorate - DOH) have implemented programs to create and strengthen GUC (Fuster et al., 2016; Donoso et al., 2014; Ravanal Salinas, 2011).

In the absence of GUCs, the WC81 establishes that the DGA is responsible for controlling and monitoring groundwater withdrawals. Evidence has shown, however, that the DGA has not had the necessary resources (human, technical, and financial) to monitor all groundwater extractions (World Bank, 2013).

\subsection{Reallocation of groundwater use rights through markets}

As previously pointed out, the WC81 established that WR are transferable so as to facilitate and achieve the efficiencies of market reallocation of water. Although private WR existed in Chile prior to 1981, the previous water codes restricted the creation and operation of efficient water markets (Hearne and Donoso, 2005). Thus, the WC81 was designed to protect traditional and customary WR and to foster economically beneficial reallocation through market transfers (Montginoul et al., 2016).

The existence of groundwater markets has been documented (Cristi et al., 2014; Hearne, 2018). The regions with the greatest GWR market transactions have been the Metropolitan region, with $73 \%$, and Araucanía, with $10 \%$ of total transactions. GWR markets have also been active in river basins in northern Chile, allowing expanding mines and growing cities to purchase water rights from farmers (Hearne, 2018). Notwithstanding, the majority of transactions have been between agricultural users, moving GWRs towards high valued agricultural export sector with resulting efficiency gains (Cristi et al., 2014; Hearne and Donoso, 2014; Donoso, 2013).

A key conclusion is that GWR markets are driven by demand from relatively high-valued water uses and facilitated by low transactions costs and are more active in those aquifers that the DGA has declared as restricted or protected and where there are GUCs present that assist in the transfer of water. For example, as Figure 25. 1 shows, in the Copiapó basin, the volume of water and number of GWR traded 
began to significantly increase as of 1994, when the DGA declared the aquifer under protection (Donoso et al., 2014). There is a second increase as of 2002 when the DGA maintained the prohibition for Sectors $1-4$ and declared restriction for Sectors 5 and 6 . This resolution reinforced the signal to water users that new GWR were not available for the Copiapó aquifer and, thus, new water demands must be satisfied through the market for GWR. In the absence of these conditions, trading has been rare and water markets have not become institutionalized in most aquifers.

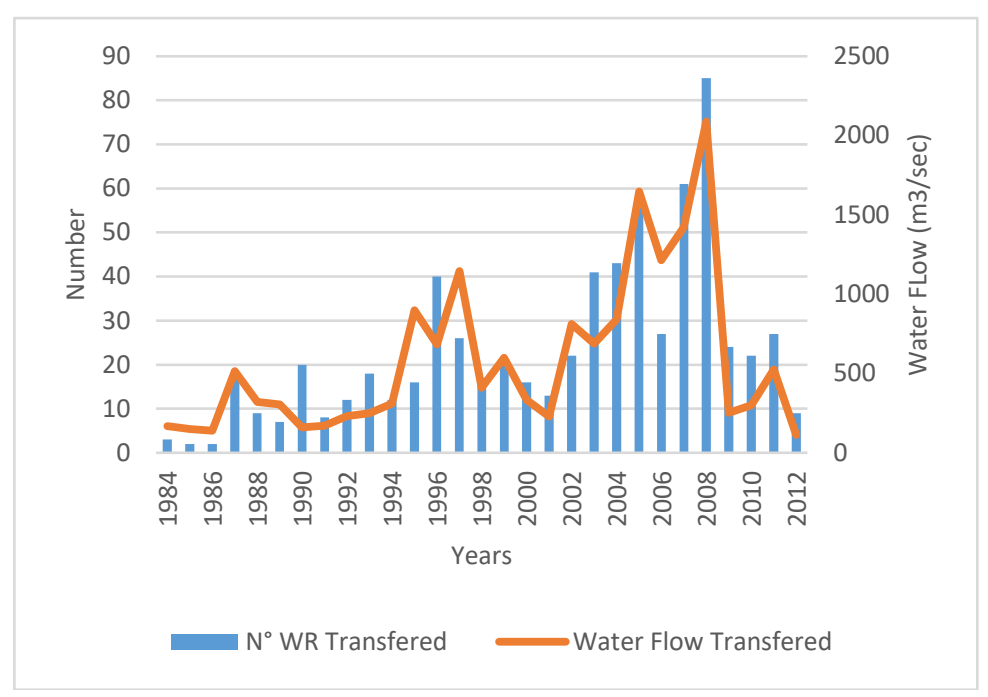

Figure 25. 1:Water flow and number of WR traded in the Copiapó Aquifer (Montginoul et al., 2016; Donoso et al., 2014).

\subsection{Summary}

Over the years there has been an acknowledgement that legal and institutional frameworks play a crucial role for effective groundwater governance and, thus, the precariousness of the treatment of groundwater in the WC81 has been covered with groundwater guidelines established by the DGA through internal administrative acts. As it stands, it considers the required instruments and mechanisms to balance growing demand and the need to protect and preserve groundwater resources.

This governance framework will in principle be effective and lead to a sustainable groundwater management to the extent that the implementation requirements are met. That is, that the state and GUCs have the technical and financial capacity to perform the required tasks to effectively implement the legal and institutional framework. Has Chile been able to apply its groundwater management policy in practice? We will investigate this through the analysis of two cases located in the 
arid region of northern Chile: the Copiapó Valley and the Pamapa del Tamarugal Aquifer.

\section{Groundwater management in the Copiapo val- ley}

\subsection{Case study presentation}

The Copiapó Valley is located in the Atacama Region, in the semi-desert region of northern Chile (Figure 25. 2). The watershed covers an area of $18,000 \mathrm{~km}^{2}$. It extends from the Andean summits, at elevations exceeding 6,000 m, as far as the sea; the river is $160 \mathrm{~km}$ in length.

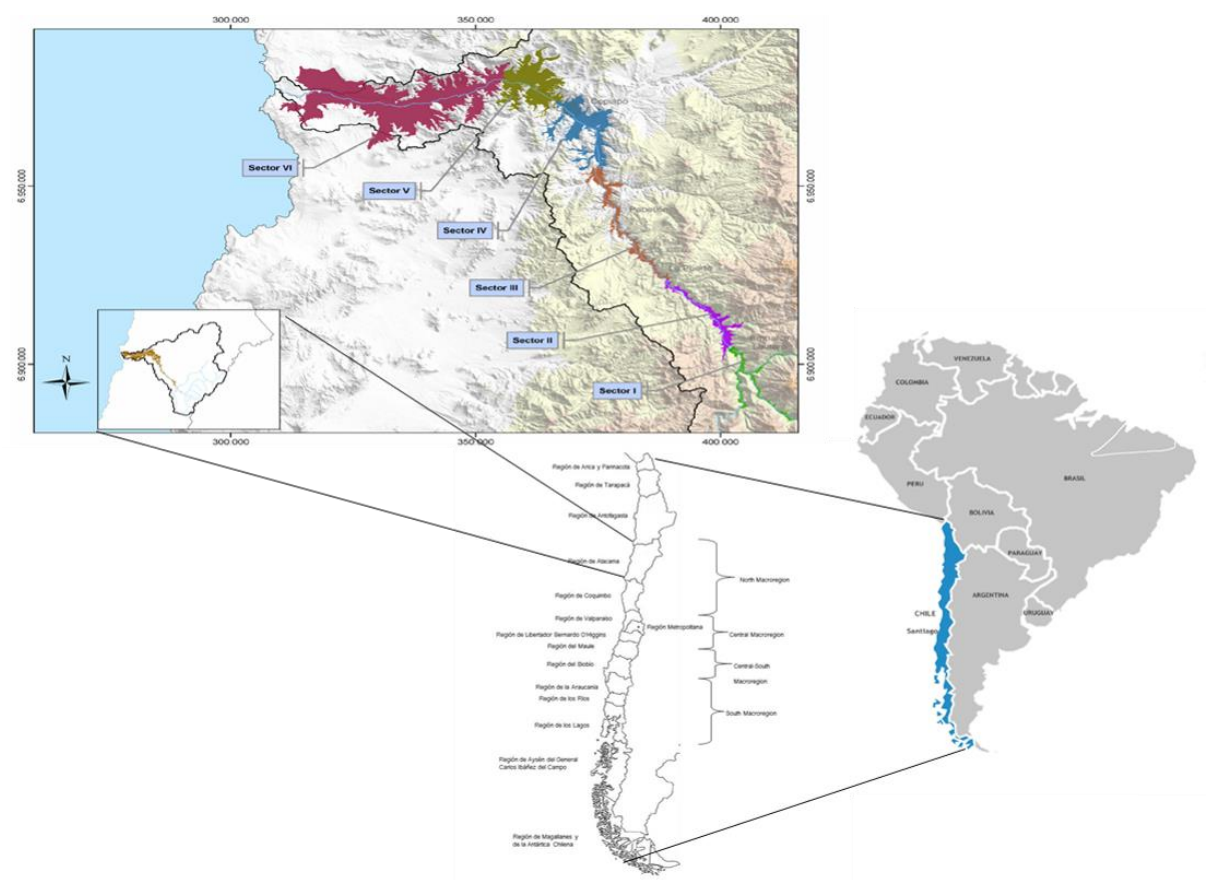

Figure 25. 2: Location of the Copiapó Valley and division of the alluvial water table into management sectors (Rinaudo and Donoso, 2018).

The groundwater resource lies in the valley bottom, over a width ranging from 1 to 5 kilometers. It constitutes a major quaternary alluvial aquifer, averaging $100 \mathrm{~m}$ in thickness and divided into six large sectors (Figure 25. 2). The aquifer's yearly 
groundwater recharge of approximately 4,000 1/s, is derived almost exclusively from melting snow and ice in the Andes and by the Lautaro Reservoir, located at the head of the river, which has an intra-annual water regulation capacity of 25,4 million $\mathrm{m}^{3}$.

The total authorized pumping flow increased from about $160 \mathrm{l} / \mathrm{sec}$ in 1965 to $13,200 \mathrm{l} / \mathrm{sec}$ in 1993 , an increase of nearly $8,200 \%$. Noting the fall in piezometric levels in Sectors 3 and 4 due to the excess pumping, respect to recharge rates, the DGA classified all 6 sectors of the Copiapó Basin as a prohibition area in 1993 (Resolución 193); thus, no new pumping permits could be granted. However, in 1994, DGA established Resolución 232 reducing the prohibition area, and allowing new GWR allocation to areas located more than $35 \mathrm{~km}$ from the river. As can be seen in Figure 25. 3, DGA continued granting GWR after the declaration of prohibition. Rinaudo and Donoso (2018) point out that this occurred, on one hand, due to a judicial sentence that required the DGA to process user's applications that had been submitted prior to the publication of the prohibition. On the other hand, expecting the DGA to declare prohibition, recognized customary groundwater users (historic usages) requested the regularization of their GWR following the procedures of the transitory second article of the WC81. Thus, total authorized pumping flow increased to about 18,500 1/sec in 2001, an increase of nearly 30\% (Figure 25. $3)$.

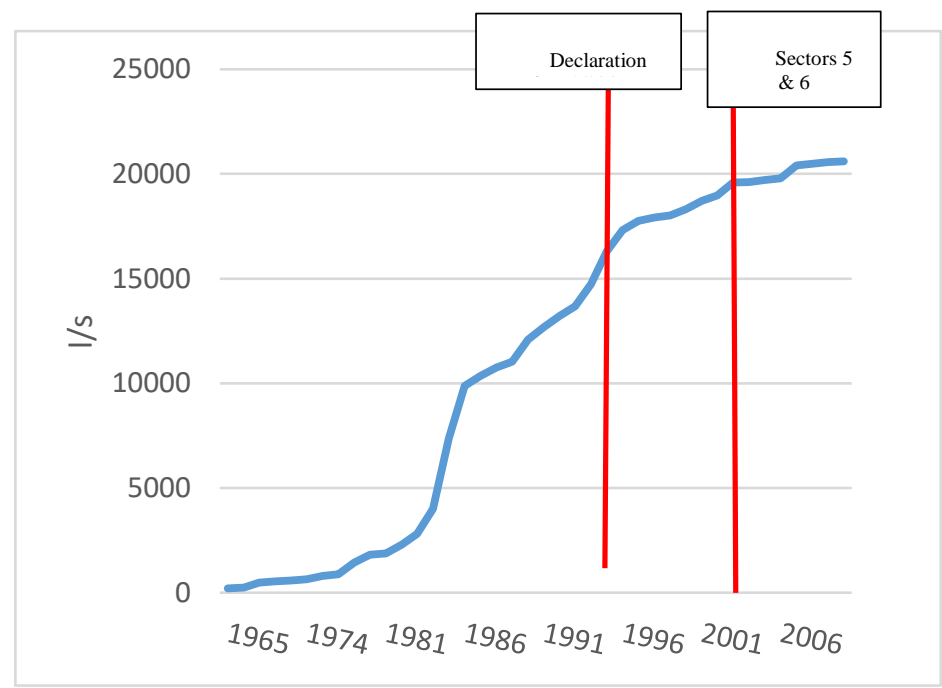

Figure 25. 3: Accumulative Granted GWR $1 /$ s (adapted from Rinaudo and Donoso, 2018)

In 2001 the DGA lifted the prohibition for sectors 5 \& 6 classifying them as a restricted zone and granting 57 provisional GWR for a total of about $450 \mathrm{l} / \mathrm{s}$, which represent $1.8 \%$ of the total authorized pumping flow rate of 25,300 1/s (Fuster et al., 
2016). At present, agriculture is the main GWR owner representing $73 \%$ of total granted GWR flows. Mining is the second most important GWR owner, with $12 \%$, while urban water supply presents the lowest participation with $7 \%$.

Since the 1980s, a number of studies have shown that withdrawals exceed by far the average recharge of the alluvial aquifer, estimated at $4 \mathrm{~m}^{3} / \mathrm{s}$ (Troncoso et al., 2012). Thus, the total available water reserve fell by about 38 million $\mathrm{m}^{3}$ per year between 1990 and 2012, the shortfall then accelerated sharply between 2005 and 2012 to 55 million $\mathrm{m}^{3}$ per year (Hidromás CEF limitada 2013). The total estimated reserve lost is approximately 830 million $\mathrm{m}^{3}$.

\subsection{Factors explaining overexploitation}

Rinaudo and Donoso (2018) researched the question of how this over-extraction situation came to be when in theory the State has the regulatory tools to avoid it. They identify the following five explanatory factors: limited knowledge of the groundwater, legal complexity and political pressures, poorly-defined water permits, compliance and enforcement problems, and inconsistency between the management of surface water and groundwater. In this section we will briefly present these factors.

\subsubsection{Limited knowledge of the groundwater}

Over the past 20 years, several studies have been conducted of the Copiapó aquifer, most of which have alerted the authorities to the danger of overexploitation (Hidromás CEF limitada 2013; Troncoso et al. 2012; DICTUC 2010; Alamos y Peralta 1987). However, these studies offered different conclusions with respect to the situation of the aquifer. For example, Uri Hammer y Asociados' (1980) study showed that extraction exceeded recharge by $18 \%$ and, thus, groundwater reserve decreased in 59 million $\mathrm{m}^{3}$ between 1970 and 1979. Just a few years later, Alamos y Peralta (1987) presented contradictory results, indicating that the aquifer could continue to be exploited without a significant reduction in piezometric levels. Given that the declaration of a groundwater resource under restriction or prohibition requires proof that there exists a serious risk of diminishing water levels, the lack of reliable technical information on Copiapó's aquifer characteristics led to a late establishment of protection areas and, thus, overallocation.

\subsubsection{Legal complexity and political pressures}

When significant reductions in piezometric levels in Sectors 3 and 4 became evident, the DGA declared the Copiapó Basin as a prohibition area in 1993. However, a year later, the declaration was modified, reducing the prohibition areas located more than $35 \mathrm{~km}$ from the river, thus allowing a number of mining projects to obtain GWR . This, together with the judicial obligation that the DGA process GWR petitions that had been submitted prior to the publication of the prohibition and the regularization of recognized customary GWR, led to an increase in the total authorized pumping flow to $18,500 \mathrm{l} / \mathrm{sec}$ in 2001 , an increase of nearly $30 \%$ with respect 
to authorized extractions in 1993; . Rinaudo and Donoso (2018) also suggest that the local authority may have been subjected to pressures from influential users, who had relations in the central government and in Santiago's political circles, to continue granting GWR.Additionally, the Instituto Nacional de Desarrollo Agropecuario (INDAP), the agency of the Ministry of Agriculture whose objective is to promote the development of small agriculture, reached an agreement with the DGA to lift the prohibition declaration for sectors 5 and 6 and classify them as a restricted zone. This allowed the DGA to grant provisional GWR in these sectors to small farmers. However, not only small farmers received provisional GWR; some mining companies were also benefited.

\subsubsection{Poorly-defined water permits}

Granting GWR based on a foreseeable use factor is a third issue that helps explain the overexploitation. The number of GWR the DGA could grant considering the foreseeable use that the beneficiary intended to make of the permit is higher given that water availability is less restrictive. Consider that a permanent and continuous GWR of 1 1/s gives the right to pump $31,500 \mathrm{~m}^{3} /$ year, if this permit is used 365 days a year, 24 hours a day. Since agricultural producers only pump water between the end of spring and the end of summer, the DGA assumed a use factor of $20 \%$ and thus a water-permit of $1 \mathrm{l} / \mathrm{s}$ for agriculture theoretically implied a total demanded volume of $6,307 \mathrm{~m}^{3} /$ year. This theoretical use factor was $75 \%$ for drinking water and the mining industry. Therefore, considering the GWR allocated to the different economic sectors, the total theoretical granted volume was 239 million $\mathrm{m}^{3} / \mathrm{year}$.

However, actual water use has increased due to improvements in water use efficiency and intersectoral market trades. Due to these factors, actual volume extractions reached 421 million $\mathrm{m}^{3} / \mathrm{year}$, which represents a $56 \%$ increase in volumetric extraction without increasing the number of granted GWR.

\subsubsection{Compliance and enforcement problems}

The WC81 establishes that water users, organized in GUC are responsible for monitoring and enforcing water extraction limit compliance. However, they have not fulfilled this obligation and, thus, the DGA has unsuccessfully tried to fill this gap. In order to implement an effective extraction monitoring system, Decree 203 of 2014 required that all groundwater users install measuring equipment and inform the DGA of their water extraction levels. However, this was not effective as only a minority of users up to date have installed measuring equipment (mainly in the downstream section of the valley) and very few inform the DGA of their extraction levels. Additionally, the random monitoring conducted by the DGA only led to seven official police reports in a 12 -year period. Therefore, this policy instrument does not incentivize stakeholders to comply since the cost of non-compliance is low; some farmers openly acknowledge that they do not comply with the terms of their water rights. 


\subsection{The challenge of collective action}

Although the Copiapó aquifer was declared under prohibition in 1993, no GUC were formed until 10 years later. The Comunidad de Aguas Subterráneas Copiapó - Piedra Colgada; Piedra Colgada - Desembocadura (CASUB), that pulls together all GWR holders of sections 5 and 6, was finally judicially constituted in 2004. In the other sectors of the aquifer, the GUCs were established judicially in 2015. CASUB is composed of users that have $424 \mathrm{WR}$ with a total water flow of 5,745 $1 / \mathrm{s}$. The participation of the different economic sectors is similar to that of the total aquifer; agriculture holding most of the GWR (representing $81 \%$ of total granted flows, according to National Water Right registry, 2017 datamining is the second most important GWR holder, with $13 \%$, while water supply presents the lowest participation with $6 \%$ Erreur ! Source du renvoi introuvable..Erreur ! Source du renvoi introuvable.

CASUB is managed by of a board of 7 elected directors. In order to guarantee that all users are represented in the board, the agricultural, mining, industrial and water supply company must have, at least, one representative in this collegiate body ${ }^{86}$. The Board presents proposals to the general assembly for approval, where the vote of each user is proportional to the number of liters per second he/she holds. It is financed by the users via a contribution proportional to the size of of the GWR(in 1/s per). The main objectives of CASUB are to (i) represent interests of its users, (ii) manage and protect its water source, (iii) regulate uses so as to insure a sustainable exploitation of the hydrogeological sectors of the aquifer, and (iv) control groundwater extractions and apply sanctions. The community offers technical and administrative support to its users and helps resolve conflicts between users and users vis-à-vis the state.

To control groundwater extractions, CASUB monitors pumping flow-rates as well as aquifer static and dynamic levels in real time through telemetry. In the case of non-compliance with the authorized flow the GUC can theoretically apply sanctions, such as to remotely cutting the power supply to the pump. However, users find that this monitoring system is not fully exploited to suppress illegal wells and ensure that users respect their extraction limits.

CASUB only became operational in 2008 and its management capacities have been limited due to the lack of rules of operation, which were only approved in 2013. However, a majority of its members do not clearly understand which are the attributions of CASUB and the DGA. This is particularly evident with respect to the delivery of information on wells, WR, and extraction levels. There is a belief that since CASUB already collects information (e.g. telemetry), users are not obliged to give additional information to CASUB or DGA, thus not complying with Law 21064. To support users help generate a sense of belonging to the community and of its duties and responsibilities, CASUB has implemented several activities

${ }^{86}$ This is not a common characteristic in GUC. 
such as a website which will soon enable users to obtain information on the levels of the water table and their dynamic trends and support tools to help manage irrigation at the farm level, which will allow individual farmers to identify faulty operations in their irrigation systems. However, most members have yet to be convinced. Rinaudo and Donoso (2018) found that only a small group of members are now fully aware of the community's significance and are actively involved in the association.

Additionally, a large proportion of CASUB's users are not aware of the legal possibility of applying a temporary extraction limit so as to reduce the groundwater reductions and tend to a sustainable extraction level. They have difficulty understanding how this mechanism would be put in place.

\section{Groundwater management in the Pampa de Tamarugal}

\subsection{The Pampa del Tamarugal aquifer}

The Pampa del Tamarugal aquifer is a major aquifer located in the far north of Chile (Atacama Desert), in the region of Tarapacá (Figure 25. 4). It lies within the Pampa del Tamarugal basin - a hyper-arid and relatively flat sedimentary basin (Central Depression) bounded in the east by the Precordillera Mountains and the Chilean Altiplano and in the west by the Coastal Range (Figure 25. 4). The precipitation in the area is almost nil, so the aquifer recharge comes from lateral groundwater flow within the piedmont area which originates from the precipitations that occur on the western flank of the Andes (Viguier et al., 2018; Scheihing et al., 2017), where the average annual precipitation ranges between 150 and $180 \mathrm{~mm}$ (Lictevout et al., 2013). Until recently, little was known about the aquifer's limits, structure and recharge (Lictevout et al., 2013). The exploited aquifer has a total estimated saturated thickness of 100 to $300 \mathrm{~m}$ (Rojas and Dassargues, 2007). The recharge was estimated to be approximately 1,180 1/s. The main natural discharge occurs through evaporation of the western and southern parts of the aquifer $(145 \mathrm{l} / \mathrm{s})$ and evapotranspiration of the tamarugo trees (900 1/s) (JICA, 1995). There is also an outflow to other aquifers estimated at 135 1/s (DICTUC, 2008).

The Pampa del Tamarugal (hereafter PdT) aquifer plays an important role in providing drinking water, as well as water for mining companies and agricultural use. 


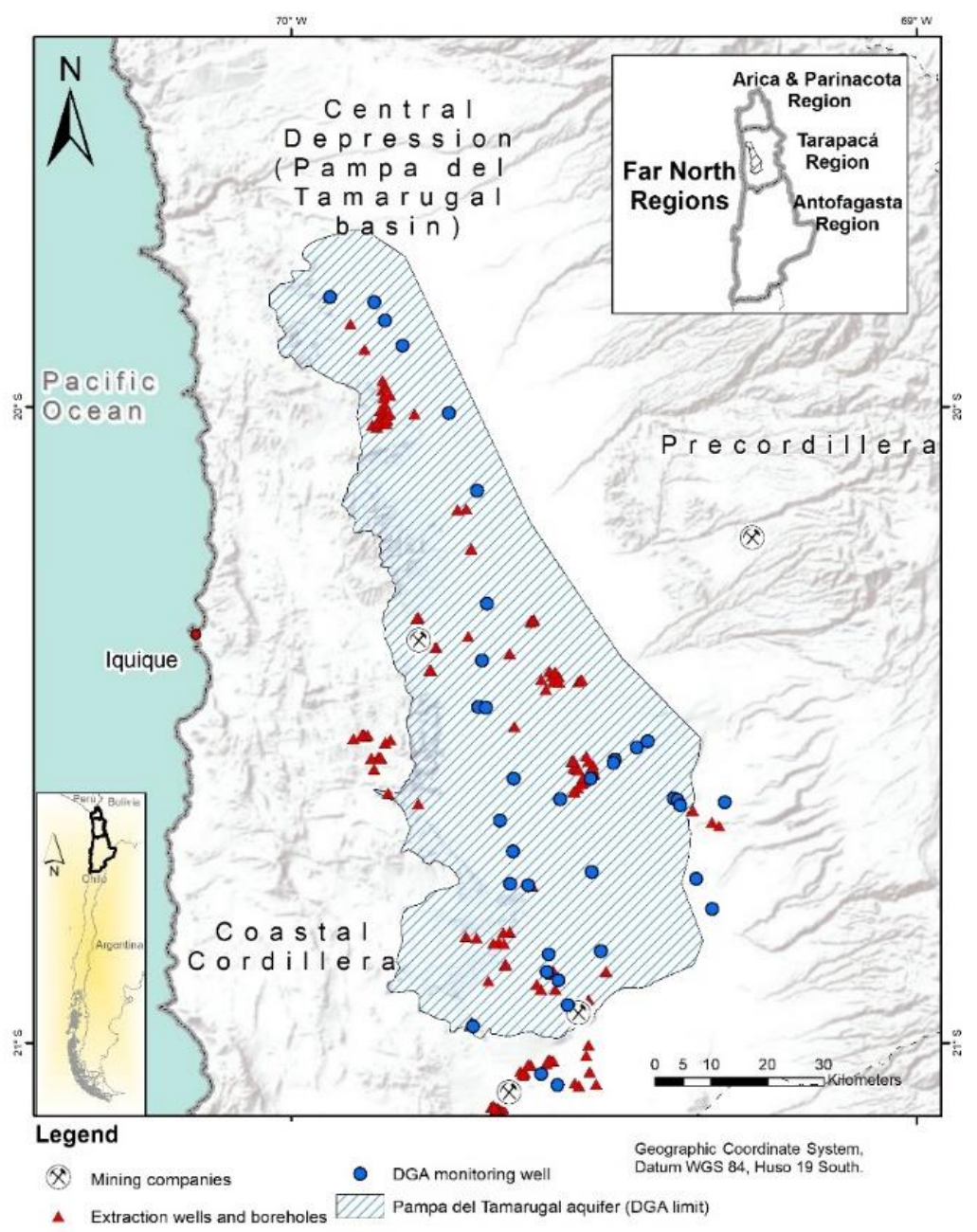

Figure 25. 4: Location of the Pampa del Tamarugal Aquifer.

\subsection{Groundwater use and management}

The PdT basin harbours the world's biggest deposit of natural nitrate and iodine which exploitation requires water for the transformation of nitrate. The growth in mining activities in the Region of Tarapacá since the 1990's also triggered a 51\% population increase between 1992 and 2017. The corresponding rise in demand for drinking water was met with groundwater from the PdT Aquifer. Small-scale farmers also pump water for irrigation purposes. In 2009, the DGA deemed the aquifer to be overused and declared it as restricted area at the beginning of 2010. 
Figure 25. 5 shows the temporal evolution of the granted extractions yields (groundwater rights) in the PdT Aquifer since the 1980s according to the national Water Rights Registry. The total cumulative granted water flow is 3,758 1/s. Similarly to what happened in Copiapo, the GWR granted for agricultural use increased from $529 \mathrm{l} / \mathrm{s}$ to $1021 \mathrm{l} / \mathrm{s}$ in 2009 , following the regularisation of groundwater use as permitted by the 2005 reform of the Water Code.

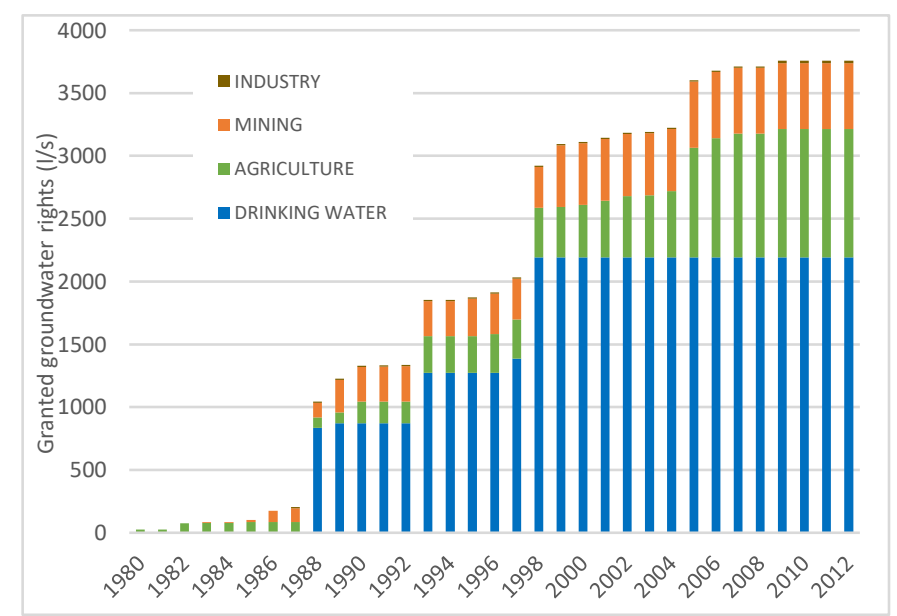

Figure 25. 5: Evolution of granted groundwater rights (as extraction yield) in the Pampa del Tamarugal aquifer since 1980 (DGA, 2016a).

However, these figures may not reflect the true situation because the registry of water rights is not exhaustive (World Bank, 2011). This is due to the fact that: i) WR obtained prior to the WC81 may not have been regularised; ii) users, law courts and particularly notaries (conservadores de bienes raíces), who legally register water rights, do not always inform the DGA, which is responsible for updating the registry, of the final resolutions for the allocation of water rights; and iii) WR transactions between users which are not required to be informed to the DGA.

Lictevout and Faysse (2018) analyzed the groundwater management of the PdT aquifer, paying particular attention to the links between: i) how information relating to groundwater resources and its uses is applied to groundwater management; and ii) the actors' strategies and discourses regarding groundwater management.

\subsection{The declaration of a restricted area}

The declaration of the PdT aquifer as restricted area was first requested in 2004 by a farmer with GWR in the PdT Aquifer based on the arguments that i) groundwater levels were decreasing at a rate of $12-20 \mathrm{~cm} /$ year in the wells monitored by the DGA; and ii) the granting of further groundwater rights would increase the 
imbalance between the recharge and use, thus representing a threat to existing water rights and protected areas. Four groundwater users objected the request: one farmer and three mining companies. No follow up was given to the request and, in 2006, the major mining company withdrew its opposition.

In 2009 the DGA issued a report (DGA, 2009), which confirmed the arguments expressed in the 2004 request and rejected all those upheld by its opponents. The analysis was based on a previous report (DGA, 1996), which used data produced by a regional study (JICA, 1995). The DGA's 2009 report demonstrated that the existing extraction rates would cause a continuous decline in groundwater levels and that the PdT Aquifer was at serious risk of depletion. The report also described the evolution of groundwater levels in the 11 wells monitored by the DGA in the PdT Aquifer. The data showed decreasing levels in seven wells, four of which showed a constant decrease since 1997 of between $0.05 \mathrm{~cm} /$ year and $0.15 \mathrm{~cm} /$ year. This led the DGA to declare the PdT Aquifer a restricted area at the beginning of 2010.

However, the report was heavily biased in order to 'force' a calculation that would lead to the establishment of a restricted area while maintaining existing water use and granting new entitlements to those who had already submitted their requests. First, the 1996 and 2009 DGA reports calculated the sustainable extraction flow based on $5 \%$ of the stored volume over a 20 -year period rather than a 50-year period as officially required. If a 50-year period had been taken into account, no additional water rights should have been granted in 1996. Moreover, the DGA did not consider recharge and natural discharge. Finally, a decrease of 0.05 to $0.15 \mathrm{~cm} /$ year of the groundwater level in a few wells may be considered limited for an aquifer whose total saturated thickness is estimated at between 100 and $300 \mathrm{~m}$. In her study of La Ligua Valley, Budds (2009) pointed out that extremely tenuous hydrogeological calculations had been used to justify the declaration of a restriction on the aquifer.

\subsection{Groundwater monitoring and control}

Every year users must declare the water flow of WRs left unused, for which a fee is paid to the DGA. Figure 25. 6 shows that the total WRs declared as unused decreased between 2010 and 2016. Although this flow is officially not pumped, the DGA considers it to be pumped in the groundwater balance. In addition, a total of $2080 \mathrm{l} / \mathrm{s}$ was allocated for drinking water (Figure 25. 6), but the used extraction flow for this purpose was 973 1/s in 2011 (Superintendencia de Servicios Sanitarios, 2013). In the same year the company declared only $145 \mathrm{l} / \mathrm{s}$ of unused rights (Figure 25. 6). However, no official information is available on the remaining flow allocated, i.e. whether it was extracted and, if so, for what purpose. So overall, official estimates of groundwater use are over-estimated. 


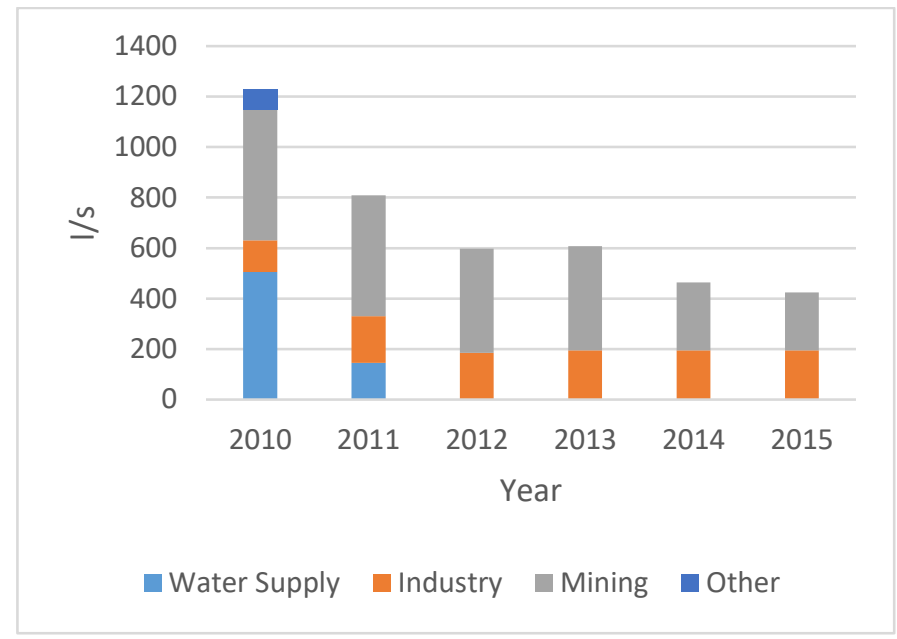

Figure 25. 6: Unused GWR (adapted from DGA, 2018).

In the Taparacá Region, users with GWR exceeding 20 1/s are required to install measuring equipment and report the volume pumped, average flow and groundwater level to the DGA (DGA, 2011). Between 2014 and 2017 the DGA conducted 58 checks to determine the amount of water actually pumped from the PdT Aquifer. The majority of these were carried out following denunciations, although only one led to a penalty for illegal extraction (DGA, 2018). In practice, small-scale users are not subject to control. However, the flow officially granted to agriculture (1021 1/s in 2009) does not correspond to the effective irrigated land in the PdT, which is much smaller. Some of those GWR may have been transferred to other uses, such as mining, or left unused (for example, waiting to sell for a profit) but this information is not available to the DGA and used for decision-making.

Large-scale users, such as mining companies, need to be more cautious, since it is possible that their actual pumping rates are monitored. In 2008 the SQM company brought a lawsuit against its main rival, Cosayach, accusing the company of using illegal wells in the PdT Aquifer. In 2011 a court ordered the closure of the illegal wells used by Cosayach. Subsequently, the mine was forbidden from using any more than the volume specified in its water rights $(28$ 1/s were legally granted before the closure of the aquifer).

\subsection{Groundwater user community}

As previously pointed out, once an aquifer has been declared a restricted area, a GUC has to be established. The process was initiated in 2015 by the DGA but did not succeed and is currently at a dead end. The reason is that farmers are firmly opposed to the GUC since, as stipulated in the Water Code, the number of votes allocated to groundwater users in the community is proportional to their groundwater rights. This results in that there were would be no farmers within the board of 
directors. The main concern of the farmers is that the community would be controlled by mining companies and the water supply company as both of them own the majority of the GWR in the aquifer.

\subsection{Creation of scientific knowledge on the aquifer}

In 2010, in light of the concern over excessive water use for mining activities, the regional government in Tarapacá, the Regional University of Arturo Prat and the National Science and Technology Research Commission created a regional research and development centre for water resources (CIDERH) as part of a national programme to decentralise science. Its primary objectives were: i) to study the surface and groundwater resources in arid zones for the development of an integrated approach to water resource management; and ii) to develop technological innovations in water processes in order to increase water supply from natural sources and promote water reuse.

The research conducted by the CIDERH improved the understanding of the PdT aquifer's structure, its recharge processes and its evolution over several decades (Viguier et al., 2018; Scheihing et al., 2017; Viguier, 2016; Moya et al., 2015; Lictevout et al., 2014). The CIDERH redefined the aquifer limits on its eastern margin far beyond the previously estimated limits (Viguier et al., 2018), involving a much larger volume of groundwater - around two times that reported by the DGA in 2009. Piezometric measurements taken in 2012, 2013 and 2014 showed that groundwater levels had decreased by an average of $5.6 \mathrm{~cm} /$ year since the $1980 \mathrm{~s}$, reaching $12-17 \mathrm{~cm} /$ year in some places. Thus, water levels dropped by 1-2 metres over two decades (1993-2014), reaching a maximum of 3-5 $\mathrm{m}$ in some areas (Lictevout et al., 2014). In other areas the level remained stable, while in several boreholes groundwater levels actually rose over the same period. Although the CIDERH reported all of its results to the regional and national offices of the DGA, these never officially endorsed the findings. In 2015 the regional government withdrew its support and funding for the centre for no official reason. As a result, the centre was forced to halt its work on surface and groundwater resources, including studying the PdT aquifer.

\subsection{Actors' actions and discourses relating to groundwater man- agement}

Although the restriction on the PdT Aquifer is considered a correct decision by actors, the decision-making process that led to the declaration of a restricted area or of the data used to justify it is unknown. In 2017 a group of PdT farmers and native american representatives filed a lawsuit against the DGA in an attempt to reverse the restriction. They claimed that the decision denied their ancestral access to groundwater, but the claim was ultimately rejected (Court of appeal of Iquique, 2017). The farmers complained that, during the process of declaration of restriction area, the remaining water rights had been divided between the mining companies, the water supply company and some well-connected farmers, who, they claimed, 
obtained GWR for speculation rather than agricultural use. In addition, many of the actors interviewed expressed the opinion that the restriction failed to improve the situation, for two reasons: i) public organisations lacked the capacity to control extractions, and ii) GWR already allocated exceeded the aquifer's capacity, which meant that continued over-extraction was inevitable.

The community leaders interviewed suggested that the problem went further and originated with governmental bias towards private companies. In their view, people at the grass roots lose out in the process. The community leaders also claimed that insufficient water rights limited agricultural activities and the possibility of obtaining public subsidies.

All the actors interviewed said that they had never discussed the question of how much water should actually be pumped from the aquifer and that far greater capacity was required to monitor actual use.

\subsection{A "status quo" situation}

The poor groundwater management in the PdT Aquifer stems from serious groundwater management policy implementation deficiencies. The high level of uncertainty in all terms of groundwater balance (in particular, outflows and actual water pumping) and the lack of an updated registry of water rights seriously compromise the implementation of a management system based on WR. This also opens the way for opportunistic use of data. This high level of uncertainty arises both from the legal setting and from insufficient financial and human resources dedicated to water resource management, in particular in State agencies.

The key decision taken on aquifer management was to restrict use in 2010, which has led to a situation of status quo. The calculations presented in support of the decision meant that existing water use, and any pending request, were unaffected.

Neither public nor private actors discussed the current or desired status of the PdT Aquifer, despite being informed of the CIDERH's research results. The CIDERH's analyses challenged the calculations made by the DGA in 2010 and 2011. For example, the results of the CIDERH analysis of the volume of water stored in the PdT Aquifer differed from the DGA's figures. Yet the dissemination of its research findings failed to break the status quo, which emerged as a result of the governance framework and actor's strategies.

Actors had very different views on water resources and their use but lacked a forum for discussion. This is a recurrent problem in Chile for issues relating to groundwater (Rinaudo and Donoso, 2018; Usón et al., 2017) and surface water (Palomino-Schalscha et al., 2016).

With regard to the PdT Aquifer, some actors avoided discussion for strategic reasons. Several were driven by an ulterior motive and not by groundwater management itself. Usón et al. (2017) describe a case where key economic actors were in favour of restricting groundwater use. Although the groundwater level drawdown of the PdT Aquifer was limited, the main mining company in the PdT area supported 
a restriction. In addition, local community leaders raised the issue of groundwater overuse in order to express their opposition to the general development model designed to promote mining, complain about the failure to share the benefits derived from mining activities and improve their visibility with regard to the local authorities. The actors did not appear to want a genuine discussion on the actual and desired status of the aquifer. Together, these strategies served to reinforce the status quo.

\section{Conclusions}

In Chile, groundwater use has increased at an exponential rate in the last decades. Even though concern for the long-term sustainability of groundwater resources has gained prominence in the agenda, groundwater policy to address the common-pool resource losses remains in its precarious stage. The evolution to date, the level of sophistication and complexity attained have not been effective to reconcile sustainable groundwater management with changing hydrogeological, technological, economic, environmental and political circumstances. Hence, Chile was not prepared, from a legal and technical point of view, for this increase in the exploitation of groundwater in the magnitude that occurred. This is evidenced by the fact that, at present, many important aquifers in Chile are under considerable stress as withdrawals, predominantly for agricultural use, outpace recharge.

An examination of the Copiapó Valley and Pampa del Tamarugal cases have shown a number of common problems:

i) Limited knowledge of the groundwater as the result of a high level of uncertainty about groundwater balance calculation (evaluation of the recharge and groundwater stock), due to the complexity of the aquifers and insufficient state groundwater monitoring networks. It is difficult to obtain reliable data that is accepted by all parties to support the decision to limit groundwater extraction. Moreover, technical studies can be manipulated to favor certain decisions, which also opens the way for opportunistic use of data, as was presented in both case studies. Given that the declaration of a groundwater resource under restriction or prohibition requires proof that there exists a serious risk of diminishing water levels, the lack of reliable technical information on Copiapó's and PdT aquifer characteristics led to a late establishment of protection areas and, thus, overallocation.

ii) Lack of forum where diverse stakeholders could gather to talk and debate about water issues. The natural instance where different actors could gather to discuss the current or desired status of groundwater resources are GUC. However, only a small number of GUC have been constituted, and there is a significant low participation in these; thus, they do not represent a valid and effective forum. Neither public nor 
private actors discussed the current or desired status of the Copiapo and PdT aquifers.

iii) Enforcement has clearly been a problem. Water users organized in GUC are responsible for monitoring and enforcing water extraction limit compliance. However, they have not fulfilled this obligation; for example, in Copiapo the data from telemetry are not used. Thus, the DGA has tried to fill this gap. Evidence has shown, however, that the DGA has not been effective due to the lack of an accurate GWR registry and the the necessary resources (human, technical, and financial) to monitor all groundwater extractions This is a prerequisite for an effective quantitative management which is missing in Chile (like in other countries, see chapter 23 for France and chaptet 22 for Australia).

iv) Over-allocation has been an inevitable problem. The regulator (and users) are usually not concerned by overexploitation until it happens, so the declaration of prohibition or restriction often comes too late. In the Copiapó case, since the 1980s, a number of studies showed that withdrawals exceeded by far the average recharge of the alluvial aquifer, however the DGA only classified the Copiapó Basin as a prohibition area in 1993, but by then the total available water reserve had significantly fallen. Moreover, users will try to obstruct the process of declaring restriction / prohibition zones when this becomes an issue, in order to obtain "last minute" water rights. For example, in Copiapó a year later after, the prohibition declaration was modified, reducing the prohibition areas located more than $35 \mathrm{~km}$ from the river, thus allowing a number of mining projects to obtain GWR. The declaration of the PdT aquifer as restricted area was first requested in 2004 but was objected by one farmer and three mining companies. Only 5 years later the DGA declared the aquifer as a restriction area.

v) Groundwater allocation is a political issue, in PdT as in Copiapo. A number of accounts suggested that the local authority may have been under pressure from influential users, to increase the total authorized pumping flow in the Copiapó aquifer after the prohibition declaration. Furthermore, the DGA declared the PdT aquifer a restricted area at the beginning of 2010 based on a biased report maintaining existing water use and granting new entitlements to those who had already submitted their requests. Even though users suffering from insufficient water supply contested the legitimacy of the initial allocation, legal complexities and political pressures led to the allocation of GWR that exceeded the established abstraction limits

vi) Overall, the State (acting through the DGA) lacks the financial, technical and human resources to implement all the provisions of the WC81. This code is very sophisticated "on the paper" but many of its dispositions are left unimplemented. For example, GUC are responsible for monitoring and enforcing water extraction limit compliance but they 
have not fulfilled this obligation and, thus, the DGA has tried to fill this gap. However, evidence has shown that the DGA has not had the necessary resources to monitor all groundwater extractions. The State has not had sufficient power to impose action to CAS, in particular in terms of data collection, and for designing rules to reduce abstraction.

vii) The legal framework established that GUC have to be established to collectively manage aquifers, however this has not happened in practice. Difficulties arise from the stage of creation of the GUC and the design of the governance. The two examples are quite contrasted, as one GUC was successfully created in Copiapo and continuously increases the range of its activity, while it could not be established in PdT. More research is needed to identify the conditions facilitating the emergence of collective action in the Chilean context.

Therefore, the analysis of the trajectory of Chile's groundwater legislation and state of its aquifers, suggests that establishing a solid and well developed legal and institutional framework is a necessary but insufficient condition to ensure that groundwater is managed sustainably. It is also important to strengthen the state and GUC's capacities and abilities to perform the key missions and tasks that the established groundwater governance framework requires.

\section{References}

Alamos y Peralta (1987) 'Analisis y evaluacion de los recursos hidrogeologicos Valle del Copiapo - III Región' D.-. MOP. Available at: http://documentos.dga.cl/REH591anexo3.pdf.

Briscoe, J., P.A. Anquita, and Peña, H. (1996). Managing water as an economic resource: Reflections on the Chilean experience. Environmental Department $\mathrm{Pa}$ pers $\mathrm{N}^{\circ}$ 62. The World Bank. http://documents.worldbank.org/curated/en/535281468768723989/pdf/multi-page.pdf

Cristi, O., Melo, O., \& Donoso, G. (2014) 'Análisis Estimación Del Precio Privado De Los Derechos De Aprovechamiento De Aguas'. Santiago, Chile: Comisión Nacional de Riego (CNR).

Budds, J. (2009). Contested H2O: Science, policy and politics in water resources management in Chile. Geoforum 40(3): 418-430.

Court of Appeal of Iquique. 2017. Decision $n^{\circ}$ 534-2017 to refuse the call of M. Godoy Villalobos et al., Iquique, unpublished document.

DGA. (1996). Determinación de la Disponibilidad de Recursos Hídricos para constituir nuevos derechos de aprovechamiento de aguas subterráneas en el sector del acuífero de la Pampa del Tamarugal. Minuta técnica 68. S.D.T. Santiago de Chile: Dirección General de Aguas (DGA). 
DGA. (2008). Manual de normas y procedimientos para la administración de recursos hídricos. S.I.T 156. S.I.T. Santiago de Chile: Dirección General de Aguas (DGA).

DGA. (2009). Declaración Área Restricción Sector Hidrogeológico Pampa del Tamarugal. Informe técnico 607. Santiago de Chile: Dirección General de Aguas (DGA).

DGA. (2011). Resolución n³95: Ordena a los titulares de derechos de aprovechamiento de agua subterránea que se indica instalar los dispositivos necesarios que permitan controlar las extracciones que realizan. Santiago de Chile: DGA, Ministerio de Obras Públicas, Gobierno de Chile.

DGA. (2013). Reglamento sobre normas de exploración y explotación de aguas subterráneas. Decreto. Santiago de Chile: Dirección General de Aguas (DGA).

DGA. (2016a) Atlas del Agua Chile 2016. Santiago, Chile: Dirección General de Aguas, Ministerio Obras Púublicas. Available at: http://www.dga.cl/DGADocumentos/Atlas2016parte1-17marzo2016b.pdf.

DGA. (2016b). Constituidas comunidades de aguas subterráneas de La Ligua y Petorca.

www.dga.cl/noticias/Paginas/DetalledeNoticias.aspx?item $=402$ (9 May 2016)

DGA. 2018. Listado de derechos afectos al pago de patente por no uso. www.dga.cl/fiscalizacion/Paginas/patentes.aspx

DICTUC. (2008). Estudio de impacto ambiental proyecto Pampa Hermosa. Estudio de impacto ambiental. Sociedad Química y Minera de Chile (SQM). Santiago, Chile.

DICTUC. (2010). Análisis integrado de gestión en cuenca del Río Copiapó. DGA - MOP

Donoso, G. (2013). The Evolution of Water Markets in Chile. In J. Maetsu (Ed.), Water Trading and Global Water Scarcity: International Perspectives (pp. 111129). RFF Press.

Donoso, G. (2015). Chilean Water Rights Markets as a Water Allocation Mechanism. In M. Lago, J. Mysiak, C. M. Gómez, G. Delacámara, \& A. Maziotis (Eds.), Use of economic instruments in water management - insights from international experience (p. 423). Switzerland: Springer-Verlag. doi:10.1007/978-3-31918287-2.

Donoso, G., Blanco, E., Vergara, A., \& Rivera, D. (2014) 'Capacitación y apoyo a comunidades de aguas subterráneas en el valle de Copiapó, Región de Atacama. Informe Final'. Comisión Nacional de Riego, Ministerio Agricultura.

Fuster, R., Kremer, C., Palacios, A. K., Haberland, J., Gálvez, R., Moya, H., et al. (2016) 'Diagnóstico Para Desarrollar Plan De Riego En Cuenca De Copiapó'. Santiago, Chile: CNR, Ministerio de Agricultura. Available at: 
https://www.cnr.gob.cl/DivisionDeEstudios/Documents/4_\%20IF\%20PGR\%20 Cuenca\%20Copiap\%C3\%B3\%20Tomo\%20I.pdf.

Gobierno de Chile (1951) 'Ley 9909, Decreto 2310, Fija los Textos Definitivos del Codigo de Aguas' Ministerio de Justicia. Santiago, Chile. Available at: https://www.leychile.cl/Navegar?idNorma=125984.

Gobierno de Chile (1969) 'Decreto 162: Fija los Textos Definitivos del Codigo de Aguas' Ministerio de Justicia. Santiago, Chile. Available at: http://documentos.dga.cl/LEG4441.pdf.

Gobierno de Chile (1981) 'DFL 1122: Fija Texto del Codigo de Aguas' Ministerio de Justicia. Santiago, Chile. Available at: https://www.leychile.cl/Navegar?idNorma $=5605$.

Gobierno de Chile (2005) 'Ley 20.017 que modifica el Código de Aguas' Ministerio de Obras Públicas. Valparaíso, Chile.

Gobierno de Chile (2014) 'Decreto 203, Reglamento y Normas de Exploración y Explotación de Aguas Subterráneas' Ministerio de Obras Públicas. Dirección General de Aguas. Santiago, Chile. Available at: http://www.leychile.cl/Navegar?idNorma=1060095.

Gobierno de Chile (2018) 'Ley $\mathrm{N}^{\circ} 21.064$ Introduce modificaciones al marco normativo que rige las aguas en materia de fiscalización y sanciones' Ministerio de Obras Públicas. Dirección General de Aguas. Santiago Chile. Available at: http://www.dga.cl/Documents/Ley21064-2018.pdf.

Hearne, R. (2018). Water Markets. In G. Donoso (Ed.), Water Policy in Chile (pp. 117-127). Switzerland: Springer International Publishing. doi:doi.org/10.1007/978-3-319-76702-4-8.

Hearne, R., \& Donoso, G. (2005). Water institutional reforms in Chile. Water Policy, 7(1), 53-69.

Hearne, R. \& Donoso, G. (2014). Water Markets in Chile: Are They Meeting Needs? In: Easter, W. and Q. Qiuqiong (eds.) Water Markets for the 21 st Century: What Have We Learned? Global Issues in Water Policy. Volume 11. Springer, Dordrecht pp. 103-126.

Hidromás CEF limitada (2013) 'Actualización de la modelación integrada y subterránea del acuífero de la cuenca del río Copiapó'. Copiapó, Chile: DGA.

JICA. (1995). The study of the development of water resources in Northern Chile. Santiago de Chile: JICA (Japon Internacional Cooperation Agency) - DGA (Dirección General de Aguas).

Kemper, K. E. (2007). Instruments and institutions for groundwater management. In M. Giordano, \& K. G. Villholth (Eds.), The agricultural groundwater revolution: Opportunities and threats for development United Kingdom: CAB International. 
Lictevout, E.; Maass, C.; Córdoba, D.; Herrera, V. and Payano, R. (2013). Recursos hídricos de la región de Tarapacá: Diagnostico y sistematización de la información. Iquique, Chile: UNAP.

Lictevout, E.; Amaro, S.; Córdoba, D. and Rodriguez, J. (2014). Estudio histórico de la variación del nivel piezometrico del acuífero Pampa Del Tamarugal, Norte de Chile. In XII Congreso Latinoamericano de Hidrogeología, Santiago de Chile, Chile.

Lictevout, E. and Gocht, M. (2017). Hydrometric network design in hyper-arid areas. Example of Atacama Desert (North Chile). Hydrology Research.

Lictevout, E., \& Faysse, N. (2018). A Doubly Invisible Aquifer: Hydrogeological Studies and Actors' Strategies in the Pampa del Tamarugal Aquifer, Northern Chile. Water Alternatives, 11(3), 592-606.

McPhee, J., de la Fuente, A., Herrera, P., Niño, Y., Olivares, M., Sancha, M. A., et al. (2012) 'Diagnóstico del Agua en las Américas'. Mexico Distrito Federal: Foro Consultivo Científico y Tecnológico, AC. Available at: http://www.ianas.org/water/book/diagnostico_del_agua_en_las_americas.pdf (Accessed: http://www.ianas.org/water/book/diagnostico_del_agua_en_las_americas.pdf).

Mechlem, K. (2016). Groundwater governance: The role of legal frameworks at the local and national level-Established practice and emerging trends. Water, 8(8), 347.

Montginoul, M., Rinaudo, J.-D., Brozović, N., \& Donoso, G. (2016). Controlling Groundwater Exploitation Through Economic Instruments: Current Practices, Challenges and Innovative Approaches. In A. J. Jakeman, O. Barreteau, R. J. Hunt, J.-D. Rinaudo, \& A. Ross (Eds.), Integrated Groundwater Management: Concepts, Approaches and Challenges (pp. 551-581). Cham: Springer International Publishing. doi:10.1007/978-3-319-23576-9_22.

Moya, C.E.; Lictevout, E.; Amaro, S.; Viguier, B.; Lira, E.; Maringue, J.; Yañez, G. and García-Perez, T. (2015). Three-dimensional hydrogeological modelling of the Pampa del Tamarugal Aquifer. Modelling with limited well-log data. In XIV Congreso Geologico Chileno, La Serena, Chile.

Oficina de Estudios y Políticas Agrarias. (2017). Región de Tarapacá: Información regional 2017. Santiago, Chile: Ministerio de Agricultura.

Ostrom, E. (2000). Collective Action and the Evolution of Social Norms. The Journal of Economic Perspectives, 14(3), 137-158.

Peña, H., Brown, E., Ahumada, G., Berroeta, C., Carvallo, J., Contreras, M., et al. (2011) 'Temas Prioritarios para una Política Nacional de Recursos Hídricos.' I. d. I. d. C. Comisión de Aguas. Available at: http://www.iing.cl/images/iing/pdf/Informe_Tem_prior_rec_hid.pdf.

Ravanal Salinas, N. V. (2011) Las Comunidades de Aguas Subterraneas en Chile: Regulación, Problemas y Prospectivas. Universidad de Chile 
Rinaudo, J.-D., \& Donoso, G. (2018). State, market or community failure? Untangling the determinants of groundwater depletion in Copiapó (Chile). International Journal of Water Resources Development, 1-21. doi:10.1080/07900627.2017.1417116.

Rivera, D. (2015). Diagnóstico jurídico de las aguas subterráneas. Ius et Praxis, 21(2), 225-266.

Rivera, D. (2018). Alumbrando conflictos: disponibilidad y asignación de derechos de aguas subterráneas en la jurisprudencia chilena. Revista de Derecho, 31(1), 159-183.

Rivera, D., Godoy-Faúndez, A., Lillo, M., Alvez, A., Delgado, V., Gonzalo-Martín, C., et al. (2016). Legal disputes as a proxy for regional conflicts over water rights in Chile. Journal of Hydrology, 535(Supplement C), 36-45. doi:https://doi.org/10.1016/j.jhydrol.2016.01.057.

Rojas, R. and Dassargues, A. (2007). Groundwater flow modelling of the regional aquifer of the Pampa del Tamarugal, northern Chile. Hydrogeology Journal 15(3): 537-551.

Salazar, C. 2003. Situación de los recursos hídricos en Chile. Con el apoyo de la Fundación Nippon. Centro del Tercer Mundo para el Manejo del Agua, A. C., México.

Scheihing, K.; Moya, C.; Struck, U.; Lictevout, E. and Tröger, U. (2017). Reassessing hydrological processes that control stable isotope tracers in groundwater of the Atacama Desert (Northern Chile). Hydrology 5(1): 3, https://doi.org/10.3390/hydrology5010003.

Superintendencia de Servicios Sanitarios. (2013). Estudio de determinación de tarifas 2013-2018 Aguas del Altiplano S.A. Tomo I. Informe final. Santiago de Chile: SISS.

Troncoso, R., M., E., Pérez, Y., Castro, R., Lorca., M., Vega, N., et al. (2012) 'Evaluación hidrogeológica de la cuenca del río Copiapó, con énfasis en cuantificación, dinámica y calidad química de los recursos hídricos superficiales y subterráneos'. Sernageomin. Available at: http://biblioteca.sernageomin.cl/opac/index.asp?param =o\%AD\%88\%92b1\%99\%8Cq\%5E\&Op=3.

Ugarte Araya, P. (2003) Derecho de Aprovechamiento de Aguas. Análisis Histórico, Extensión y Alcance en la Legislación Vigente. Universidad de Chile

Uri Hammer y Asociados (1980) 'Plan Maestro de Acción Inmediata para el Desarrollo de los Recursos de Agua y Suelo del Valle de Copiapó'. Dirección de Riego - MOP.

Usón, T. J.; Henríquez, C. and Dame, J. (2017). Disputed water: Competing knowledge and power asymmetries in the Yali Alto basin, Chile. Geoforum 85: 247-258. 
Valdés-Pineda, R.; Pizarro, R.; García-Chevesich, P.; Valdés, J.B.; Olivares, C.; Vera, M.; Balocchi, F.; Pérez, F.; Vallejos, C.; Fuentes, R.; Abarza, A. and Helwig, B. (2014). Water governance in Chile: Availability, management and climate change. Journal of Hydrology 519: 2538-2567.

Vergara, A., Arévalo, G., Muñoz, G., Rivera Bravo, D., \& Vergara, C. (2011). Codigo de Aguas Comentado. Santiago, Chile: Abeledo Perrot Legal Publishing Chile.

Vergara, A., Donoso, G., Rivera Bravo, D., Blanco, E., \& Moyano, V. (2013). Aguas y energía: propuestas para su autogobierno y resolución especializada de conflictos. In I. Irarrázaval, M. Morandé, de A., \& M. Letelier (Eds.), Concurso Políticas Públicas: Propuestas para Chile Santiago: Salesianos Impresores.

Vergara, A., \& Rivera, D. (2018). Legal and institutional framework of water resources. In G. Donoso (Ed.), Water Policy in Chile (pp. 67-85). Switzerland: Springer International Publishing.

Vicuña, S., Garreaud, R. D., \& McPhee, J. (2011). Climate change impacts on the hydrology of a snowmelt driven basin in semiarid Chile (journal article). Climatic Change, 105(3), 469-488. doi:10.1007/s10584-010-9888-4.

Vicuña, S., Meza, F., Bustos, E., \& Poblete, D. (2012). Los nuevos desafíos a la gestión de los recursos hídricos en Chile en el marco del Cambio Global. (Paper presented at the Desafíos del recurso hídrico en Chile, Santiago, Chile)

Viguier, B.; Jourde, H.; Lira, E.; Yáñez G.; Leonardi, V.; Moya, C.; García Pérez, T.; Maringue, J. and Lictevout, E. (2018). Assessment of the geometry, boundaries and preferential recharge zones of a regional aquifer in 1 dryland piedmonts by geophysical and hydro(geo)logical surveys: case of the Pampa del Tamarugal Aquifer (Northern Chile). Journal of South American Earth Sciences 86: 366-383.

Viguier, B. (2016). Caractérisation des facteurs de contrôle de la recharge et des écoulements souterrains a différentes échelles de temps en zone de piedmont aride a hyper-aride. PhD Thesis, University of Montpellier, France.

World Bank. (2011). Diagnóstico de la gestión de los recursos hídricos. Santiago, Chile: Dirección General de Aguas, Ministerio de Obras Públicas, Chile. http://www.dga.cl/eventos/Diagnostico\%20gestion\%20de\%20recursos\%20hidri cos\%20en\%20Chile_Banco\%20Mundial.pdf

World Bank. (2013). Estudio para el mejoramiento del marco institucional para la gestión del agua. Dirección General de Aguas, Ministerio de Obras Públicas de Chile. http://reformacodigodeaguas.carey.cl/wp-content/uploads/2014/09/Informe-Banco-Mundial-Estudio-para-el-mejoramiento-del-marco-institucional.pdf

Zañartu Rosselot, J. H. (2001). Aguas Subterráneas: ¿Necesidad De Un Nuevo Enfoque? Revista de Derecho Administrativo Económico de Recursos Naturales, III(2), 539-545. 